\title{
UDC 141.1:130.31
}

DOI: https://doi.org/10.26661/hst-2020-4-81-08

ТЕСЛЕНКО, Т. В.

Дніпровський національний університет залізничного транспорту імені В. Лазаряна (Дніпро,Україна)

E-mail: c.spas.dp@i.ua

ORCID iD: https://orcid.org/ 0000-0002-5810-3569

Дніпровський національний університет залізничного транспорту імені академіка В. Лазаряна (ДНУЗТ), вул. Лазаряна, 2, м. Дніпро, 49010, Україна

Dneprovsk National University of Railway Transport Named after Academician $V$. Lazaryan, 2 Lazaryan Street, 49010 Dnepro, Ukraine

\section{НАУКОВО-ЕПІСТЕМОЛОГІЧНА ЕВОЛЮЦІЯ ПОНЯТІЙНО- КАТЕГОРІАЛЬНОГО АПАРАТУ ФІЛОСОФІЇ ЕКОНОМІКИ ЯК НОВОГО ФІЛОСОФСЬКОГО ЗНАННЯ}

\begin{abstract}
Анотація. Актуальність дослідження у тому, що філософія економіки як новий науковий напрямок повертає економіку до життя, а життя до економіки. Філософія економіки звертається до понять економічного дискурсу на кшталт добра і зла, етики й моралі. Батько сучасної економіки Адам Сміт був професором етики, в основі творів якого була людина економічна, економічна реальність, які він пояснював математичними й економічними моделями, намагався показати зв'язок між економікою та антропологією, філософією, релігієзнавством, соціологією, психологією й політологією. Мета статті - концептуалізація нових знань про понятійнокатегоріальний апарат філософії економіки як нового наукового напрямку. Завдання дослідження: 1) розкрити історію становлення філософії економіки та дати обгрунтування понятійно-категоріального апарату; 2) проаналізувати основні концепти філософії економіки у контексті збереження розмаїття ідей і сприяння їхньому взаємозбагаченню; 3) дати аналіз концептів сучасної філософії економіки - людського капіталу, диференціації, спеціалізації, технології, «кругової економіки» та їх впливу на економічний розвиток. Методологія - використання науково-епістемологічного знання як основи емпіричного дослідження концептів і концепцій філософії економіки, що конституюється у методах аналізу і синтезу, абстрагування, порівняння, історичного і логічного, системності i структурованості, та виявляється в ідеях, смислах, диспозиціях, що дозволяють здійснити гносеологічно-праксеологічну побудову, щоб осмислити онтос, соціум, природу, економіку. Філософія економіки розглядається в контексті взаємозв'язку філософії, логіки, метафізики з метою відтворити сучасні методологічні концепції, щоб реконструювати нову економічну реальність та вирішити нові проблеми у дискурсосмисленні економічного соціуму. Наукова новизна дослідження - використання багатозначної філософської логіки та ії моделей-структур для обгрутування філософії економіки як нового філософського знання, нового наукового напрямку та дисципліни. Результат. У результаті соціально-філософського аналізу розкрито історію становлення філософії економіки та представлено понятійнокатегоріальний апарат; проаналізовано основні концепти філософії економіки у контексті збереження розмаїття ідей i сприяння їхньому взаємозбагаченню; представлено аналіз концептів сучасної філософії економіки - людського капіталу, диференціації, спеціалізації, технології, «кругової економік» та їх впливу на економічний розвиток. В результаті філософського аналізу філософії економіки підвищено загальний рівень обізнаності про стрімкість розвитку філософії економіки в
\end{abstract}

() Тесленко Т. В., 2020 
умовах технологічної революції, окреслено базові економічні проблеми й запропоновано шляхи їх подолання.

Ключові слова: філософія економіки, понятійно-категоріальний апарат, людина економічна, цифровізація суспільства.

\section{Актуальність}

Актуальність дослідження у тому, що філософія економіки як новий науковий напрямок повертає економіку до життя, а життя до економіки. Філософія економіки звертається до понять економічного дискурсу на кшталт добра i зла, етики й моралі. Батько сучасної економіки Адам Сміт був професором етики, в основі творів якого була людина економічна, економічна реальність, які він пояснював математичними й економічними моделями, намагався показати релевантно-логічний зв'язок між економікою та антропологією, філософією, релігієзнавством, соціологією, психологією й політологією, які витікають дискурсивним чином із самих своїх аргументів. В сучасних умовах виникає нова інтегральна філософія економіки, яка сприяє виживанню людства, формує передовий культурний авангард суспільства,здатний

переформатовати вивести його із стадії саморуйнування i створити справжні, всеохопні механізми інклюзії, про необхідність якої так давно говорили соціальні й політичні філософи і яка так довго вважалася утопією; приведе суспільство до самоорганізації [1].

Аналіз останніх досліджень i публікацій, 3 яких започатковано розв'язання даної проблеми і на які спирається автор.

В дослідженні використано роботи філософії людських ресурсів, що лежать в ос нові філософії економіки, та еволюції економічних концепцій У. Петті, А.Сміта, Д.Ст. Мілля, Ж.Б.Сея, Н. Сеніора, Л.Якоба, К.Маркса, Ф.Ліста. І. Г. фон Тюнена, У. Багехота, Е.Енгеля, Г.Сінджвіка, Л.Вальраса, І.Фішера. Сучасна теорія філософії економіки сформувалася навколо концепції людських ресурсів і виникла у 5060-i pp. XX ст. у рамках Чикагської економічної школи. У числі їі засновників Г. Беккер та його робота «Людський капітал» (1964 p.), Б. Вейсброд, Т. Шульц, Дж. Мінцер, Л. Хансен. Дана концепція отримала свій розвиток у роботах М. Блауга, С. С. Боулса, Й. БонПорета, Дж Псахаропулоса. Одним i3 найбільш цікавих напрямків концепції аналізу людських ресурсів є роботи Е.Флемхольця, М. Александера, Р. Германсона, Р. Вудрафа, Д. Боуероса.

\section{Мета дослідження}

концептуалізація нових знань про понятійно-категоріальний апарат філософії економіки як нового наукового напрямку та аналіз концептів сучасної філософії економіки та їх вплив на економічний розвиток.

\section{Завдання дослідження:}


1) розкрити історію становлення філософії економіки та дати обгрунтування понятійнокатегоріального апарату;

2) проаналізувати основні концепти філософії економіки в контексті збереження розмаїття ідей i сприяння їхньому взаємозбагаченню;

3) дати аналіз концептів сучасної філософії економіки людського капіталу, диференціації, спеціалізації, технології, «кругової економік» та їх впливу на економічний розвиток.

Методологія - використання науково-епістемологічного знання як основи емпіричного дослідження концептів і концепцій філософії економіки, що конституюється у методах аналізу i синтезу, абстрагування, історичного i логічного, системності і структурованості, та виявляється в ідеях, смислах, диспозиціях, що дозволяють здійснити гносеологічнопраксеологічну побудову, щоб осмислити онтос, соціум, природу, економіку. Філософія економіки розглядається в контексті взаємозв'язку філософії, логіки, метафізики 3 метою відтворити сучасні методологічні концепції, щоб реконструювати нову економічну реальність та вирішити нові проблеми у дискурсосмисленні економічного соціуму [2]. Наукова новизна дослідження

використання багатозначної філософської логіки та iï моделейструктур для обгрунтування філософії економіки як нового філософського знання, нового наукового напрямку та дисципліни.

Майже в усіх галузях промисловості цифрові технології створили нові революційні способи поєднання продуктів i послуг i розмили традиційні кордони між цифровою, реальною і доповненою реальністю, привели до підключеності до мереж, роздробленості та соціальної напруженості. Рух людей довкола світу впливає на світовий рівень добробуту, мобільність буде відігравати у суспільстві більшу роль, ніж зараз. Присутність у цифровому світі стрімко зростає протягом останніх 25 років. Процес технологічних інновацій винайдення, комерціалізація, широке запровадження та використання найпотужнішим рушієм примноження статків та збільшення добробуту впродовж всієї історії людства. Четверта промислова революція пропонує можливість продовжити сходження на шляху до людського розвитку. Тому наша мета - показати еволюцію понятійнокатегоріального апарату від становлення філософії економіки стародавніх часів до філософії економіки Четвертої промислової революції [12].

\section{В основі дослідження:}

\section{1. Історія становлення} філософії економіки та обгрунтування понятійнокатегоріального апарату.

Філософія економіки сягає своїм корінням до стародавніх часів, близько 400 p. до н.е. Ще Ксенофонт писав, що «навіть якщо 
в людини немає свого господарства, вона щось таки знає про економіку (від давньогрецького ойкономія, де «ойкос» - дім, «домогосподарство») [4]. Колись економіка була наукою про управління домогосподарством, згодом стала підгалуззю релігійних, теологічних, етичних та філософських дисциплін, а потім почала поступово змінюватися, часом розгубила свої кольори i перейшла у технократичний світ. Двісті років тому більшість країн світу перебували на межі бідності, проте деякі європейські та північноамериканські країни досягли неймовірного рівня розвитку в економіці, у покращенні охорони здоров'я та різних можливостей для більшості своїх громадян, залишивши далеко позаду інші країни світу. Сьогодні здобутки філософії економіки, що детерміновані

промисловою

Четвертою революцією, сприяють поліпшенню урядування, інтенсивного використання вебтехнологій, що ставлять безпрецедентні завдання 3 огляду на швидкий темп змін [5]. Саме філософія економіка акумулює стрімкість технологічних змін та значущість їх наслідків. Цифрові технологіï та інфраструктура глобальної взаємодії докорінно змінюють традиційний підхід до роботи й оплати праці, адже виникають нові типи робочих місць, яким притаманні гнучкість i тимчасовість (так звана «економіка на вимогу»), що сприяє тому, що в сучасних умовах змінюеться предмет і об'єкт дослідження філософії економіки. Ці професії не лише приводять до нової хвилі інновацій й дозволяють людям користуватися перевагами гнучкішого робочого графіку, але ще й породжують схвильованість через зниження рівня захищеності держави [6]. У процесі занурення світової економіки у цифрову царину доступність надійної інтернет-інфраструктури стає вирішальною передумовою для процвітання. Уряди потребують розуміння потенціалу технологічних досягнень. Треба ще уміти та поширювати технології, щоб рухатися до інформаційного суспільства 3 глобальним каналом зв'язку, що сприяє також і науковоепістемологічній еволюції понятійно-категоріального апарату філософіï економіки як нового філософського знання [7]. Проблеми цифрової ізоляції (або цифрового бар'єру) набуває актуальності, оскільки без можливості доступу до мережі Інтернет або через невміння ним користуватися людям дедалі складніше брати участь у цифровій економіці та нових формах громадянської активності.

\section{Понятійно-категоріальний} апарат пройшов еволюцію від становлення філософії економіки стародавніх часів до філософії економіки Четвертої промислової революції.

Процес економічного розвитку, безумовно, $\epsilon$ найпомітнішою подією останніх десятиліть. Економічний розвиток як концепт 
філософії економіки - це не просто зростання доходів, це поява цілісної системи взаємодії людей 3 метою стимулювати інновацій, які скорочують час, необхідний людям для задоволення власних потреб. I донині, незважаючи на те, що ми знаємо, що економічний розвиток може відбутися практично скрізь, і навіть знаємо деякі умови, за яких він може відбутися, досягти його за наказами неможливо [9]. У більшості випадків економічні реформи не зумовлюють прискорення економічного зростання і більшості прискорень зростання не передували великі зміни в економічній політиці, інституційних заходах, політичних обставинах або зовнішніх умовах, а також ними не супроводжувалися. У роботі «Еволюція всього» Метт Рідлі відмічає, що з точки зору філософії економіки, країни, якими керують торговці в інтересах торговців, не були досконалими, але вони завжди були більш процвітаючими, мирними та культурними, ніж країни, якими керують деспоти. Фінікія проти Єгипту; Афіни проти Спарти; китайська імперія Сун проти монголів, італійські міста-держави проти Іспанії Чарльза V; Республіка Об'єднаних провінцій (Голландська Республіка) проти Франції Людовика XIV; нація крамарів (Англія) проти Наполеона; сучасна Каліфорнія проти сучасного Ірану; Гонконг проти Північної Кореї; Німеччина 1980-х проти Німеччини 1930-х pp.» [11]. Більше немає сумніву у тому, що вільна торгівля має кращі економічні та гуманітарні досягнення, ніж командно-адміністративний уряд i прикладів цього безліч. Проте як свідчить аналіз, торгівля не $\epsilon$ досконалою, вона стимулює марнотратство, заохочує до надмірного споживання [12].

В основі понятійнокатегоріального апарату філософії економіки як нового наукового напрямку концепт «Ното oеconomicus», або «людина економічна» - концепт, у якому людина діє раціонально на основі своїх егоїстичних інтересів так, аби досягла своїх суб'єктивних цілей. Уперше цей термін використали критики економіста Джона Стюарта Мілля як спрощену модель загальноприйнятої людської поведінки. Мілль стверджував, що в очах політичної економіки на характер людини впливає іiі статус у суспільстві. Людина розглядається лише як істота, що прагне багатства та здатна оцінити i порівняти ефективність різних засобів для досягнення цієї цілі. Модель Ноmo oeconomicus - це дуже контраверсійне спрощення людської поведінки, тому у цієї моделі дуже багато критиків навіть iз середовища економістів [13]. Цифровий розвиток не знає кордонів, тому неминуче виникає питання щодо впливу технологій на географію - i навпаки. В умовах Четвертої промислової революції суперкористувач інформаційними технологіями - це спеціальний обліковий запис в операційній системі, власник якої має свої повноваження на виконання всіх операцій без винятку, тому слід 
забезпечити, щоб Четверта промислова революція відбулася під контролем людини i орієнтувалася на людину. Чим швидше нові технології масштабуватимуться, тим нагальніше нам треба буде адаптуватися до їхніх проривних викликів. Технології Четвертої промислової революції не зупиняться, а проникнуть у фізичний світ довкола нас і стануть частиною нас. Однак, мабуть, найбільшим занепокоєнням щодо четвертої промислової революції $€$ те, що згадані цінності не розподілятимуться справедливо - i через це збільшення нерівності може навіть підірвати єдність суспільства. Проактивні кроки у бік ціннісного підходу до технологій можуть допомогти нам відновити баланс, a не вічно залишатися позаду, але для цього слід зберегти розмаїття ідей і сприяти їхньому взаємозбагаченню у контексті викликів Четвертої промислової революції [14].

\section{Основні концепти філософії економіки B контексті збереження розмаїття ідей i сприяння взаємозбагаченню.}

Філософія економіки не єдина царина, яку хочуть зробити складнішою, ніж вона $є$ насправді. У будь-якій професійній галузі, де потрібні спеціальні знання,професійна мова сприяс порозумінню між фахівцями, але ускладнюе спілкування із зовнішнім світом. Філософію економіки слід вивчати так, щоб ознайомитися із різноманітним и економічними аргументами й навчитися критично оцінювати 3 урахуванням економічних умов, моральних цінностей і політичної мети, так як вона допомагає зрозуміти економічний світ 3 філософської точки зору. Філософія економіки вивчається за теоретичним підходом, а не за предметом і від неї ми намагаємося отримати якомога точніше пояснення різних економічних явищ [15]. В основі економіки полягає раціональний вибір, тобто вибір на під ставі ретельного і систематичного розрахунку максимального досягнення мети за допомогою обмежених ресурсів. Економіка вивчає господарство, що включає в себе гроші, працю, технології, міжнародну торгівлю, податки. На думку філософів, філософія економіки вивчає життя, Всесвіт і все інше. Хоч би якою важливою була економічна теорія, вона обмежена в часі і просторі. Тож для iii дієвого застосування потрібно достеменно знати, які технологічні й інституційні сили діють на ринках, у галузях промисловості та в країнах, які ми намагаємося аналізувати за допомогою теорії [16]. Філософія економіки розглядає проблеми автоматизації, які впливають на ринки країн, що розвиваються. Тут вона може несподівано зруйнувати перевагу у виробництві трудомістких товарів i послуг. Такий сценарій міг би знищити економіки деяких успішних країн $\mathrm{i}$ регіонів. Зрозуміло, що жодна 
країна не зможе процвітати, якщо інноваційні екосистеми міст не отримуватимуть постійного підживлення. За всіх історичних епох міста були двигунами економічного зростання, розквіту i соціального прогресу. Швидкість i масштаби, 3 якими міста, за підтримки гнучких нормативних баз щодо економічної політики, поглинають і застосовують технології, визначають їхню подальшу спроможність конкурувати на ринку кадрів [17].

Збереження розмаїття ідей i сприяння взасмозбагаченню.

Недостатньо просто знати, що існують різні підходи до економіки. Розмаїття економічних теорій слід плекати й навіть примножувати. Оскільки різні підходи розглядають різні питання й аналізують ту саму проблему під різними кутами, знання низки шкіл, а не лише декількох 3 філософської точки зору дозволяє нам більш повно й збалансовано розглядати складну сутність того, що зветься економікою [18].

Це важливо в довготривалій перспективі, оскільки філософія економіки об'єднує багато теоретичних підходів, які зможуть краще пояснити швидкоплинний світ. Наше життя є підтвердженням цього: світове господарство зазнало б краху, як під час Великої депресії 1929 року, якби на початку світової фінансової кризи 2008 року уряди найпотужніших країн не вирішили відмовитися від ринкових методів і перейти до кейнсіанської політики. Філософія економіки зводиться до того, що збереження розмаїття також недостатньо, різні підходи до економіки можуть багато чого взяти один від одного, а наше розуміння від цього лише збагатиться [19].

Девелопменталістська традиція та шумпетерівська школа ведуть взаємовигідний діалог: перша висуває теорії, що допомагають зрозуміти широкий контекст технологічного розвитку, а інша відповідає теоріями, які пояснюють механізми

технологічних

виникнення Марксистська, інституціональна та поведінкова школи протягом тривалого часу обмінюються думками, - причому цей обмін часто доволі ворожий, - iз приводу розуміння ворожих процесів фірми, а особливо відносин між робітниками й капіталістами. I кейнсіанська, й поведінкова школи завжди зважали на психологічні чинки, але нещодавно взаємозбагачення цих шкіл породило нову цікаву галузь поведінкові фінанси. При цьому взаємозбагачення можливе між школами, що здаються несумісними. Навіть якщо вони стоять на різних політичних позиціях, класицисти (праві), кейнсіанці (центристи) та марксисти (ліві) - всі вони розглядають суспільство як сукупність класів [20].

Австрійці та кейнсіанці сперечаються від 1930-х років, але вони (a також поведінкові економісти та інституціоналісти) сходяться на тому, що світ дуже складний і непевний, а нам бракує 
раціональності, щоб із ним упоратися.

Австрійці, інституціоналісти та поведінкові економісти погоджуються, що люди - багаторівневі істоти, які, за термінологією інституціоналістів, складаються 3 інстинктів, звичок, вірувань, розуму, хоча деякі пребдставники австрійської школи незадоволено розглядають своїх колег із цього переліку, вважаючи їх лівими. Філософія економіки виходить 3 того, що нам варто знати дещо про розмаїття підходів до економіки. За кожною економічною політикою чи корпоративною дією, що впливає на наше життя - на мінімальну зарплату, залучення фахівців із зовні, соціальне забезпечення, безпеку продуктів харчування, пенсії тощо, - стоїть певна економічна теорія, яка надихнула на ці дії, або надала обгрунтування того, чого прагнуть досягти можновладців. Знання різних економічних теорій, їхніх переваг i недоліків не $є$ певною заплутаною справою, яку варто залишити фахівцям. Це невід'ємний етап розуміння економіки, а ще - внесок у спільні зусилля, завдяки яким розвивається філософія економіки, що сприяє пошукам філософіï істини [21].

\section{2. Концепти}

сучасної філософії економіки - людського капіталу, спеціалізації, диференціації, «кругової економік» та їх впливу на економічний розвиток

Концепт людського капіталу. Витоки концепту людського капіталу можна знайти у роботах У. Петті, А. Сміта, Д.Ст. Мілля, Ж. Б. Сея, Н. Сеніора, Л.Якоба, К. Маркса, Ф.Ліс та І. Г. фон Тюнена, У. Багехота, Е. Енгеля, Г. Сінджвіка, Л. В. Альраса, I. Фішера. Сучасна теорія людського капіталу виникла у 50-60-і pp. ХХ ст. у рамках Чикагської економічної школи. У числі ऑiі засновників Г. Беккер та його робота «Людський капітал» (1964 p.), Б. Вейсброд, Т. Шульц, Дж. Мінцер, Л.Хансен. Дана концепція отримала свій розвиток у роботах М. Блауга, Є С. Боулса, Й. БонПорета, Дж. Псахаропулоса, О.Р. Лейарда. Одним iз найбільш цікавих напрямків концепції аналізу людських ресурсів $є$ роботи Е. Флемхольця, М. Александера, Р. Германсона, Р. Вудрафа, Д. Боуероса. Саме ж поняття людського капіталу першим ввів А. Сміт, який вважав, що людський капітал - це накопичені знання i вміння членів суспільства, які дають право на отримання доходу.

При цьому Сміт включав у поняття фіксованого капіталу майстерність і корисні здібності людини, яка отримала освіту шляхом кропіткої праці, які можливо уподібнити машині, яка дорого коштує. Людський капітал складається 3 набутих знань, навичок, мотивацій та енергії, якими наділені людські істоти і які можуть використовуватися на протязі певного періоду часу, це форма капіталу, що може бути джерелом майбутніх заробітків i задоволення потреб, що є частиною 
людини. Передумови появи сучасної концепції людського капіталу у філософській науці пов'язані у першу чергу 3 традиціями становлення нового інноваційно-інформаційного

суспільства: розвитком науковотехнічного прогресу, новим етапом інформаційної соціальними, економічними i структурними зсувами в економіці, зростанням якості удосконалення трудових ресурсів, прискоренням темпів нематеріального накопичення. Тому не випадково дану концепцію ми відносимо до комплексу теорій інноваційноінформаційного суспільства, що розвиваються у руслі благо приємного оптимістичного сценарію соціально-економічного розвитку, при здійсненні якого працівник сам стає власником «нових» економічних ресурсів знань, кваліфікації, досвіду, інформації [22].

Концепт «диференціації» як стратегія ринку

Основою диференціації можуть бути властивості самого продукту, система реалізації, маркетинговий підхід або доволі широкий діапазон інших факторів. Ефективність діяльності компанії, якій вдалося досягти i підтримувати сталу диференціацію, буде значно вищою від середніх показників по галузі, якщо націнка перекриватиме додаткові витрати на унікальність продукту. Компанія-диференціатор має постійно приділити увагу витратам, оскільки навіть надвисокі ціни можуть не дати бажаного прибутку за перевищених витрат у галузі, якщо оцінка перекриватиме додаткові витрати на унікальність продукту. Таким чином, компанія диференціатор повинна спрямовувати свою діяльність на досягнення паритетного або наближеного до паритетного становища відносно конкурентів через зниження витрат у тих царинах, що не впливають на напрям диференціації. Філософія i логіка стратегії диференціації вимагає, щоб компанія запроваджувала диференціацію тих властивостей продукту, які б відрізняли його від продукту конкурентів. На практиці стратегію диференціації часто плутають зі стратегією фокусування на диференціації. Але між ними $\epsilon$ істотна відмінність: компанія, що обрала стратегію диференціації, будуватиме iii на базі тих характеристик продукту, які представляють цінність для всіх покупців (наприклад, це стратегія компанії IBM у виробництві комп'ютерів). Компанія ж, яка вибрала фокусування на диференціації, буде шукати такі сегменти, де у покупців є цілком специфічні потреби, i намагатиметься задовольнити потреби саме таких покупців (наприклад, у комп'ютерній галузі це стратегія компанії Gray Research) [23].

Концепт «спеціалізації».

Концепт «спеціалізації» розвинувся на фабричному виробництві, де майже все роботизовно. За збігом обставин, на одній такій фабриці усю ефективність розподілу роботи 
усвідомив Адам Сміт, якого вважають основоположником ідеї економічної спеціалізації, в основі якої кожен спеціалізується на тому, у чому буде для суспільства найкориснішим. Спеціалізація, що супроводжується обміном, $\epsilon$ джерелом економічного зростання. Сучасна версія Адама Сміта стверджує, що стихійний та добровільний обмін товарами та послугами приводить до поділу праці, в якому люди спеціалізуються на тому, що вони мають виробляти якісно. Ця стратегія зосереджується на виборі вузького сегмента конкуренції у певній галузі і пристосовує свою діяльність так щоб обслуговувати саме їх. Оптимізуючи свою стратегію для цільових сегментів, компанія прагне досягти в них конкурентної переваги, навіть якщо загальної конкурентної переваги в галузі вона й не має. Стратегія спеціалізації має два варіанти. Обираючи спеціалізацію на витратах, компанія намагається отримати переваги за витратами у своєму цільовому сегменті; обираючи спеціалізацію на диференціації - зосереджується на диференціації властивостей продукції для свого цільового сегмента. Обидва сегменти, як відмічає Майк Портер, спираються на відмінності між цільовими сегментами компанії та іншими сегментами галузі. У цільовому сегменті повинні бути споживачі 3 незвичайними потребами, або система виробництва i/чи обслуговування цільового сегмента повинна відрізнятися від цих систем в інших сегментах галузі. Компанія, що обрала стратегію спеціалізації може досягти конкурентної переваги, присвятивши свою діяльність тому, щоб задовольнити особливі потреби певного ринкового сегмента. Компанія, що обрала стратегію спеціалізації, має переваги перед конкурентами [24].

\section{Концепт «технології».}

Концепт «технологіï» в сучасних умовах інформаційного суспільства має вплив на розвиток економіки та на іï конкурентні переваги. Технології пронизують усі види діяльності задля створення вартості та беруть участь в утворенні зв'язків між видами діяльності, можуть мати значний вплив на витрати і диференціацію, впливаючи на конкурентну перевагу. Технологічний прогрес використовує фактори, що визначають витрати й унікальність на користь компаніі, так як покращує загальну структуру галузі. «Технологічна стратегія - це підхід стратегії до розвитку та використання технологій. [25]. Інновації - це один із основних способів нападу на конкурентів, які давно присутні на ринку. Технологічна стратегія - це один із елементів загальної конкурентної стратегіï. Компаніям часто доводиться робити вибір покращити стару технологію чи вкласти гроші в розробку нової. Стійкість технологічної бази сприяє технологічному лідерству та появі 
нових термінів типу «кругова
економіка».

Концепт «кругова економіка».

Реворт Кейт у роботі «Економіка пончика. Як економісти XXI століття бачать світ» вводить нове поняття «кругова економіка» [ c.191-192].

Промислове виробництво почало перетворення 3 пагубного на відновлювальне через таке поняття, як «кругова економіка». Воно має відновлювальний характер, бо використовує нескінченний потік сонячної енергії, щоб перетворити матеріали на корисні товари та послуги. Відновлювальна економіка у вигляді метелика або кругова економіка, розроблена Фондом Елен Макартур включає відновлювальні матеріали, до яких відносить біогенні i технічні елементи, які слід:

1) регенерувати й фіксувати вартість на кожній стадії розпаду;

2) відновити, відремонтувати повторно, використати, оновити, переробити, яка існує зав рахунок відновлювальної енергії, позбувається всіх токсичних хімікатів і відходів [26].

Уся річ у простому принципі: замість опинятися на звалищах, продукти одного виробничого процесу стають матеріалами для наступного. Щоб ця схема працювала, ми повинні сприймати всі матеріали як частини одного 3 двох класів. Ці або біологічні речовини, тобто грунт, рослини чи тварини, або технічні речовини, такі як пластик, синтетика і метали. Ці два тип й становлять крила метелика, у межах яких матеріали $\begin{array}{llll}\text { ніколи не } & \text { викидають, } & \text { а } \\ \text { використовують } & \text { знову, знову } & \text { й } \\ \text { знову завдяки } & \text { переробленню } & \text { й }\end{array}$ відновленню. Що стосується першого біологічного крила, то усі речовини зрештою споживаються i відновлюються через землю. Щоб мати змогу нескінченно їх використовувати, не можна збирати ці дари швидше, ніж природа їх відновлює. До того ж треба організовувати виробничі процеси у такий спосіб, щоб у результаті віддавати природі те, що ми в неї позичаємо. На іншому крилі метелика розташовані технічні речовини, такі ж як метали чи синтетичні волокна. Вони не розкладаються в природний спосіб, тож ми повинні їх відновлювати, інакше кажучи, ремонтувати, повторно використовувати, переробляти. Застосувавши цей принцип у всіх видах діяльності, ми фактично позбудемося відходів у XXI столітті. Проте жодна промислова петля не здатна переробити й повторно використовувати $100 \%$ матеріалів. У відновлювальній економіці матеріали не викидаються, а опиняються у круговому потоці. Та справжні зміни приходять лише 3 новим усвідомленням значення цінності. Економічна цінність полягає не в потоці товарів i послуг, а в їхніх відновлювальних властивостях. Цінність становлять не лише створені людиною активи (трактори чи будинки), а й самі люди (їні навички, чесноти), здорова біосфера (від лісів до океанів) i наші знання ( від Wikipedia до нашого геному). Та 3 
часом навіть і ці форми багатства 3 часом зникають, тому що як вчить філософія, що лише один вид багатства невідворотно рухається крізь час - сила життя. Джанін Беньюс намагається втілити в життя свій проект щодо створення так званих «щедрих міст» («розумних міст»): людських поселень, що існують в межах живої природи [27].

\section{Інтегральна економіки.}

Філософія економіки повинна використати закони, принципи, категорії інтегральної метатеорії, покликаної об'єднати в одну діалектичну цілісність науки про світ і науки про людини, традиції східного містицизму i традиції західного раціоналізму, щоб розширити картину економічного світу. Інтегральна філософія економіки як найсучасніший науковий напрямок спирається на суперінклюзивні, найновіші, найбільш цілісні стадії розвитку 3 тих, що віднайшла культурна еволюція. За інтегральним світоглядом стоїть не просто якась ідея (як, скажімо, за прагматизмом) - він спирається на реальну територію рівня розвитку буття i свідомості (а саме на інтегральну стадію). Він дає нам проявлення (в усіх квадрантах буття) розвитку, (через усі рівні і лінї розвитку), пробудження (на всіх стадіях розвитку), очищення (від тіньових елементів). Інтегральна філософія економіки охоплює весь зміст минулого i відкриває всі перспективи майбутнього, вона виступає передовим краєм культурної еволюції, явищем, якого людство ще не знало. Це передовий край, природний i автентичний, неминучий процес формування якого вже почався. Інтегральній стадії філософії економіки властива установка на «подолання i включення» всіх попередніх стадій розвитку, які існували до цього. [28]. Поява інтегральної філософії економіки - «тектонічний зсув», «монументальний стрибок свідомості», що відбувся у зв'язку з пандемією коронавірусу COVID-19 та виробленням умов iï подолання. Формування нового типу свідомості виступає супротивом проти роздробленого, регресивного, репресивного, зловорожого стану пандемії, в якому опинилася людина i швидко тоне наш світ. Бачення ширшої картини, інтегральний світогляд звільняє від відчуття задухи, яке виникає, коли зосереджуєшся лише на проблемах коронавірусу. Якщо осмислити цей феномен як появ еволюційної самокорекції, яка намагається прокласти обхідні шляхи в ситуації, коли попередні теорії збанкрутіли, то людство шукає нового авангарду філософської думки, здатного вести за собою, тож з'являється бодай i якась надія. Культурна еволюція, що відбувається і у філософському бомонді, породжує новий, інтегральний авангард, що з'являється у багатьох країнах, здатний повністю звільнити нас від проблем кризового буття i повернути на правильну траєкторію 
розвитку, що інтегрує роздроблені ідеї виживання людства. Інтегральна стадія розвитку інтегральної філософії економіки перша стадія в історії, яка вважає, що всі попередні стадії важливі, вона не повністю 3 ними погоджується, проте приймає їх i включає [29]. У кожному разі, всі попередні стадії - це певний етап у загальному розвитку людства загалом, причому жодну стадію не проминеш i не перестрибнеш. Зневажати й ненавидіти попередні стадії - це саморуйнування, тому для інтегральної філософії економіки кожна попередня стадія важлива, тому стрибок в інтегральну стадію філософії економіки - це кардинальний, інноваційний стрибок. Інтегральний підхід філософії економіки здатен майже автоматично зупинити катастрофу божевілля, пов'язаного з пандемією коронавірусу, й повернути людство на культурну стадію свого розвитку [30]. Саме це, зрештою, намагається зробити еволюція у процесі своєї самокорекції буття i свідомості. Це ще один, хоча й навіть кардинально новий, інший, більший, вимір «порядку», який виникає 3 «хаосу». Інтегральна філософія економіки створює потужне регенеративне поле, здатне компенсувати дизфункції суспільства та в багатьох випадках допомогти його ефективності [31]. У нас ніколи не було культурного авангарду, який інтегрував би у собі всі попередні стадії розвитку, а це відбувається тоді, коли формується критична маса населення, здатна оцінити функції інтегральної філософії, завдяки якій у суспільстві може відбутися перелом i кардинальний зсув до позитивного розвитку суспільства та економіки. I тоді відбудеться епохальна безпрецедентна зміна у внутрішній структурі людського буття i свідомості, - відмічає К.Швабс [32].

\section{ВИСНОВКИ}

Слід змінити переконання на більш конструктивний, людиноорієнтований погляд на філософію економіки, у центрі якої відбувається взаємодія людини i машини, людини i технології; ідентифікувати цінності, пов'язані 3 певними технологіями; 3'ясувати, як технології впливають на повсякденний людський вибір та сприяти ухваленню рішення. Технології Четвертої промислової революції трансформують суспільство та переформатують майбутнє. У результаті виникає потреба у переформатуванні предмета i об'єкта дослідження філософії економіки в умовах Четвертої промислової революції та чіткіше сформулювати етичні основи, нормативні стандарти та моделі ціннісного управління та дослідити новий понятійнокатегоріальний апарат. Філософія економіки має грунтуватися на обговоренні ширших питань щодо суспільства, в якому людина прагне жити і бути щасливою. У культурі, філософії політики, філософії економіки, в медіа та соціальних мережах, у пошукових системах, а також у свідомості людини 
запанував нездоровий прояв

постмодернізму, що відкидає істину, стверджуючи їі вірогідність. Філософія економіки повинна віднайти концептуальний ключ до розуміння сучасних політичних i культурних подій, до розуміння всього, що відбувається у сфері економіки, a, отже, перейти до формування нової інтегральної філософії і філософії економіки.

\section{СПИСОК ВИКОРИСТАНИХ ДЖЕРЕЛ}

1. Ажажа М. А., 2006.Теоретико-медологічні засади концепції людського капіталу. Ефективність сучасного менеджменту організації: зб. наук. праць. Х.: ХІМБ. 267-271.

2. Ажажа М. А., 2012. Моніторинг як інструмент забезпечення якості державних та муніципальних послуг. Гуманітарний вісник Запорізької державної інженерної академії. 50. 270-277.

3. Ажажа М. А., 2007. Інвестиції в освіту як фактор інтелектуального прогресу. Соціальна перспектива i регіональний розвиток:[наук.-пр. журн.]. Запоріжжя: ТOB «КК-Альянс». 37-40.

4. Buhaichuk, Oksana, 2019. Strategies of information and innovation activity development at enterprise in digital conditions. HUMANITIES STUDIES: Collection of Scientific Papers. Zaporizhzhia: ZNU. 1 (78). 75-85.

5. Браян Крістіан, Гріффітс Том, 2020. Життя за алгоритмами. Як робити раціональний вибір / пер. з англ. Катерина Диса. К.: Наш формат. 376.

6. Voronkova, Valentyna, Metelenko, Natalya, Nikitenko, Vitalina, Silina, Iryna, 2019. System analysis of the economy of sustainable development as environmentally balnced and socially oriented one. HUMANITIES STUDIES: Collection of Scientific Papers. Zaporizhzhia: ZNU. 1 (78). 86-97.

7. Воронкова В. Г., 2008. Філософія гуманістичного менеджменту (соціальноантропологічні виміри): монографія. Запоріжжя: РВВ ЗДІА. 254.

8. Воронкова В. Г., Капітаненко Н. П., Нікітенко В. О., 2019. Правові засади захисту інтелектуальної власності у цифровому суспільстві. Journal «ScienceRise: Juridical Science. 4 (10). 32-37.

9. Воронкова В. Г., 2008. Глобалізація як процес універсалізації стосунків між державою та ринком. Гуманітарний вісник Запорізької державної інженерної академії. 35. $15-35$.

10. Воронкова В. Г., Тесленко Т. В., 2020. Становление и развитие цифровых технологий как фактор реализации четвертой промышленной революции. Журнал Белорусского государственного университета. Философия. Психология. Изд-во Белорусского государственного ун-та. 2. 4-11.

11.Zhuravel, Kristina, 2019. Concept of flexible management at enterprise in digitalization and lean production conditions. HUMANITIES STUDIES: Collection of Scientific Papers. Zaporizhzhia: ZNU. 1 (78). 98-107.

12. Кириченко, Микола, 2019. Вплив цифрових технологій на розвиток людського і соціального капіталу в умовах діджиталізованого суспільства. HUMANITIES STUDIES: Collection of Scientific Papers. Zaporizhzhia: ZNU. 1 (78). p. 108-129.

13. Melnik, Victoria, 2019. Agile-management 3.0 concept as a factor of technological progress development in the digital society. HUMANITIES STUDIES: Collection of Scientific Papers. Zaporizhzhia: ZNU. 1 (78). 130-139.

14. Nikitenko V.O., 2013. Problem field of the geokul' turnogo phenomenon: scientific approaches Gìleâ (Research Bulletin): Col. Sciences. Ave: publishing SCIENCE LLC NVP. 500-504.

Научно-эпистемологическая эволюция понятийно-категориального аппарата философии экономики как нового философского знания 
15. Олексенко, Р. І., Ортіна Г. В., 2018. Особливості інноваційно-інвестиційної політики антикризового розвитку реального сектору економіки України. Економічний вісник Запорізької державної інженерної академії. 5 (17). 33-39.

16. Олексенко, Р. І., 2017. Формування концепції креативної особистості як фактор креативно-знаннєвої економіки в умовах викликів глобалізації. Гуманітарний вісник Запорізької державної інженерної академії. 71. 118-126.

17. Портер, Майкл, 2019. Конкурентна перевага. Як досягати стабільно високих результатів / пер з англ. Ірина Ємельянова, Ірина Гнатковська. К. : Наш формат. 624.

18. Публічне управління та адміністрування в умовах інформаційного суспільства: вітчизняний і зарубіжний досвід [Електронний ресурс] : монографія, 2017 / ред. С. Чернов, В. Воронкова, В. Банах, та ін. Запоріжжя : ЗДІА. 603.

19. Рідлі, Метт. 2019. Еволюція всього / пер. $з$ англ. М. Солдаткіної. Київ: Видавнича група КМ-БУКС. 336

20. Реворт, Кейт, 2019. Економіка пончика. Як економісти XXI століття бачать світ. К. : Наш формат. 296.

21. Соснін, О. В., Воронкова, В. Г., Ажажа, М. А., 2016. Філософія гуманістичного менеджменту (соціально-політичні, соціально-економічні, соціально-антропологічні виміри): навчальний посібник. Запоріжжя: Дике поле. 356.

22. Управління людськими ресурсами: філософські засади: навч. посібник, 2006 / В. Г. Воронкова, А. Г.Беліченко, О. М. Попов та ін. К.: Професіонал, 576.

23. Рижова, I. С., 2009. Становлення і розвиток дизайну як духовнопрактичного феномена в інформаційно-культурному просторі, 2009. Гуманітарний вісник Запорізької державної інженерної академії. 36. 211-224.

24. Рижова, I. С., 2009. Дизайн в технічних вузах. Гуманітарний вісник Запорізької державної інженерної академії. 37. 87-95.

25. Teslenko T. V., 2018. «Spirit/mind-body» dihotomy and its impact on the formation of «homo creativus» in the context of economic philosophy: methodological bases. Гуманітарний вісник Запорізької державної інженерної академії: збірник наукових пращь. Запоріжжя: «Видавництво ЗДІА».75. 53-64.

26. Тесленко Т. В., 2019. Антропологические измерения категорий «дух-душа-тело» и их трансформация в экономической, духовной и культурной природе человека. Proceedings of the XIII International Scientific and Practical Conference Social and Economic Aspects of Education in Modern Society Vol.3, Warsaw, Poland. May 25.13-19.

27. Tovarnichenko Vladimir, 2019. Pseudoscience and information security in smartsociety. HUMANITIES STUDIES: Collection of Scientific Papers. Zaporizhzhia: ZNU. 1 (78). $15-27$.

28. Фостер Провост, Том Фоусетт. Data science для бізнесу. Як збирати, аналізувати і використовувати дані. Київ : Наш формат, 2019. 400 с.

29. Фурсін О. О., 2012. Механізми соціально-орієнтованого державного управління. Автореферат кандидатської дисертації 3 спеціальності «Механізми державного управління»: 25.00. 02. Харків.

30. Фурсін О. О., 2012. Шляхи і напрями удосконалення механізмів соціальноорієнтованого державного управління на рівні регіону. Гуманітарний вісник Запорізької державної інженерної академії. 48. 172-188.

31. Фурсін О. О., 2008. Формування моделі стійкого економічного розвитку в умовах конкурентоспроможності. Гуманітарний вісник Запорізької державної інженерної академії. 33. 223-230.

32. Шваб Клаус. Четверта промислова революція, Формуючи четверту промислову революцію. Харків : Клуб сімейного дозвілля, 2019. 426 с.

\section{REFERENCES}

() Тесленко Т. В., 2020 
1. Azhazha M. A., 2006. Teoretyko-medolohichni zasady kontseptsii liudskoho kapitalu// Efektyvnist suchasnoho menedzhmentu orhanizatsii: zb. nauk. prats. X.: XIMB. 267-271.

2. Azhazha M. A., 2012. Monitorynh yak instrument zabezpechennia yakosti derzhavnykh ta munitsypalnykh posluh. Humanitarnyi visnyk Zaporizkoi derzhavnoi inzhenernoi akademii. 50. 270-277.

3. Azhazha M. A., 2007. Investytsii v osvitu yak faktor intelektualnoho prohresu. Sotsialna perspektyva i rehionalnyi rozvytok:[nauk.-pr. zhurn.]. Zaporizhzhia: TOV «KSKAlians». 37-40.

4. Buhaichuk, Oksana, 2019. Strategies of information and innovation activity development at enterprise in digital conditions. HUMANITIES STUDIES: Collection of Scientific Papers. Zaporizhzhia: ZNU. 1 (78). 75-85.

5. Braian Kristian, Hriffits Tom, 2020. Zhyttia za alhorytmamy. Yak robyty ratsionalnyi vybir / per. z anhl. Kateryna Dysa. K.: Nash format. 376.

6. Voronkova, Valentyna, Metelenko, Natalya, Nikitenko, Vitalina, Silina, Iryna, 2019. System analysis of the economy of sustainable development as environmentally balnced and socially oriented one. HUMANITIES STUDIES: Collection of Scientific Papers. Zaporizhzhia: ZNU. 1 (78). 86-97.

7. Voronkova, V. H., 2008. Filosofiia humanistychnoho menedzhmentu (sotsialnoantropolohichni vymiry): monohrafiia. Zaporizhzhia: RVV ZDIA. 254.

8. Voronkova, V. H., Kapitanenko N. P., Nikitenko V. O., 2019. Pravovi zasady zakhystu intelektualnoi vlasnosti u tsyfrovomu suspilstvi. Journal «ScienceRise: Juridical Science. 4 (10). 32-37.

9. Voronkova V. H., 2008. Hlobalizatsiia yak protses universalizatsii stosunkiv mizh derzhavoiu ta rynkom. Humanitarnyi visnyk Zaporizkoi derzhavnoi inzhenernoi akademii. 35. $15-35$.

10. Voronkova V. H., Teslenko T. V., 2020. Stanovlenye y razvytye tsyfrovykh tekhnolohyi kak faktor realyzatsyy chetvertoi promyshlennoi revoliutsyy. Zhurnal Belorusskoho hosudarstvennoho unyversyteta. Fylosofyia. Psykholohyia. Yzd-vo Belorusskoho hosudarstvennoho un-ta. 2. 4-11.

11. Zhuravel, Kristina, 2019. Concept of flexible management at enterprise in digitalization and lean production conditions. HUMANITIES STUDIES: Collection of Scientific Papers. Zaporizhzhia: ZNU. 1 (78). 98-107.

12. Kyrychenko, Mykola, 2019. Vplyv tsyfrovykh tekhnolohii na rozvytok liudskoho i sotsialnoho kapitalu v umovakh didzhytalizovanoho suspilstva. HUMANITIES STUDIES: Collection of Scientific Papers. Zaporizhzhia: ZNU. 1 (78). p. 108-129.

13. Melnik, Victoria, 2019. Agile-management 3.0 concept as a factor of technological progress development in the digital society. HUMANITIES STUDIES: Collection of Scientific Papers. Zaporizhzhia: ZNU. 1 (78). 130-139.

14. Nikitenko, V. O., 2013. Problem field of the geokul' turnogo phenomenon: scientific approaches. Gileâ (Research Bulletin): Col. Sciences. Ave: publishing SCIENCE LLC NVP. 500-504.

15. Oleksenko, R. I., Ortina, H. V., 2018. Osoblyvosti innovatsiino-investytsiinoi polityky antykryzovoho rozvytku realnoho sektoru ekonomiky Ukrainy. Ekonomichnyi visnyk Zaporizkoi derzhavnoi inzhenernoi akademii. 5 (17). 33-39.

16. Oleksenko, R. I., 2017. Formuvannia kontseptsii kreatyvnoi osobystosti yak faktor kreatyvno-znannievoi ekonomiky $\mathrm{v}$ umovakh vyklykiv hlobalizatsii. Humanitarnyi visnyk Zaporizkoi derzhavnoi inzhenernoi akademii. 71. 118-126.

17. Porter, Maikl, 2019. Konkurentna perevaha. Yak dosiahaty stabilno vysokykh rezultativ / per z anhl. Iryna Yemelianova, Iryna Hnatkovska. K. : Nash format. 624.

Научно-эпистемологическая эволюция философии экономики как нового философского знания понятийно-категориального аппарата 
18. Publichne upravlinnia ta administruvannia $\mathrm{v}$ umovakh informatsiinoho suspilstva: vitchyznianyi i zarubizhnyi dosvid [Elektronnyi resurs] : monohrafiia, 2017 / red. S. Chernov, V. Voronkova, V. Banakh, ta in. Zaporizhzhia : ZDIA. 603.

19. Ridli, Mett, 2019. Evoliutsiia vsoho / per. z anhl. M. Soldatkinoi. Kyiv: Vydavnycha hrupa KM-BUKS. 336

20. Revort, Keit, 2019. Ekonomika ponchyka. Yak ekonomisty XXI stolittia bachat svit. K. : Nash format. 296.

21.Sosnin, O. V., Voronkova, V. H., Azhazha, M. A., 2016. Filosofiia humanistychnoho menedzhmentu (sotsialno-politychni, sotsialno-ekonomichni, sotsialno-antropolohichni vymiry): navchalnyi posibnyk. Zaporizhzhia: Dyke pole. 356.

22. Upravlinnia liudskymy resursamy: filosofski zasady: navch. posibnyk, 2006 / V. H. Voronkova, A. H.Belichenko, O. M. Popov ta in. K.: Profesional, 576.

23. Ryzhova, I. S., 2009. Stanovlennia i rozvytok dyzainu yak dukhovno-praktychnoho fenomena v informatsiino-kulturnomu prostori, 2009. Humanitarnyi visnyk Zaporizkoi derzhavnoi inzhenernoi akademii. 36. 211-224.

24. Ryzhova, I. S., 2009. Dyzain v tekhnichnykh vuzakh. Humanitarnyi visnyk Zaporizkoi derzhavnoi inzhenernoi akademii. 37. 87-95.

25. Teslenko T. V., 2018. «Spirit/mind-body» dihotomy and its impact on the formation of «homo creativus» in the context of economic philosophy: methodological bases. Humanitarnyi visnyk Zaporizkoi derzhavnoi inzhenernoi akademii: zbirnyk naukovykh prats. Zaporizhzhia: «Vydavnytstvo ZDIA». 75. 53-64.

26. Teslenko, T. V., 2019. Antropolohycheskye yzmerenyia katehoryi «dukh-dusha-telo» y ykh transformatsyia $\mathrm{v}$ эkonomycheskoi, dukhovnoi y kulturnoi pryrode cheloveka. Proceedings of the XIII International Scientific and Practical Conference Social and Economic Aspects of Education in Modern Society Vol.3, Warsaw, Poland. May 25.13-19.

27. Tovarnichenko, Vladimir, 2019. Pseudoscience and information security in smartsociety. HUMANITIES STUDIES: Collection of Scientific Papers. Zaporizhzhia: ZNU. 1 (78). $15-27$.

28. Foster, Provost, Tom, Fousett, 2019. Data science dlia biznesu. Yak zbyraty, analizuvaty i vykorystovuvaty dani. Kyiv : Nash format. 400.

29. Fursin O. O., 2012. Mekhanizmy sotsialno-oriientovanoho derzhavnoho upravlinnia. Avtoreferat kandydatskoi dysertatsii z spetsialnosti «Mekhanizmy derzhavnoho upravlinnia»: 25.00. 02. Kharkiv.

30. Fursin O. O., 2012. Shliakhy i napriamy udoskonalennia mekhanizmiv sotsialnooriientovanoho derzhavnoho upravlinnia na rivni rehionu. Humanitarnyi visnyk Zaporizkoi derzhavnoi inzhenernoi akademii. 48. 172-188.

31. Fursin O. O., 2008. Formuvannia modeli stiikoho ekonomichnoho rozvytku v umovakh konkurentospromozhnosti. Humanitarnyi visnyk Zaporizkoi derzhavnoi inzhenernoi akademii. 33. 223-230.

32. Shvab Klaus, 2019. Chetverta promyslova revoliutsiia, Formuiuchy chetvertu promyslovu revoliutsiiu. Kharkiv : Klub simeinoho dozvillia. 426.

TESLENKO, TATYANA - PhD in Economics, Philosophy, Associate Professor, Associate Professor of the Department «Economics and management», Dneprovsk National Universityof Railway Transport Named after Academician V. Lazaryan (Dnipro, Ukraine)

E-mail: c.spas.dp@i.ua,

ORCID iD: http://orcid.org/0000-0002-5810-3569 
SCIENTIFIC-EPISTEMOLOGICAL EVOLUTION OF THE CONCEPTUAL AND CATEGORY APPARATUS OF THE PHILOSOPHY OF ECONOMICS AS A NEW PHILOSOPHICAL KNOWLEDGE

\begin{abstract}
The relevance of the study is that the philosophy of economics as a new scientific direction returns the economy to life, and life to the economy. Philosophy of economics refers to the concepts of economic discourse such as good and evil, ethics and morality. The father of the modern economics, Adam Smith was a professor of ethics, whose works were based on economic human, economic reality, which he explained by mathematical and economic models, tried to show the connection between economics and anthropology, philosophy, religion study, sociology, psychology and political science.The purpose of the article is conceptualization ofthe new knowledge about the conceptual and categorical apparatus of the philosophy of economics as a new scientific direction. The objectives of the study: 1) to provide a history of the formation of the philosophy of economics and provide a substantiationfor the conceptual and categorical apparatus; 2) to analyze the basic concepts of the philosophy of economics in the context of preserving the diversity of ideas and promoting their mutual enrichment; 3) to analyze the concepts of the modern philosophy of economics - human capital, differentiation, specialization, technologies, "circular economy" and their impact on economic development.Methodology is the use of scientific and epistemological knowledge as a basis for empirical study of concepts and conceptions of the philosophy of economics, constituted in the methods of analysis and synthesis, abstraction, comparison, historical and logical, systematic and structuredness and manifested in ideas, senses, dispositions that allow epistemological praxeological construction to comprehend the ontos, society, nature, economy.Philosophy of economics is considered in the context of relationship of philosophy, logics, and metaphysics in order to reproduce the modern methodological conceptions to reconstruct a new economic reality and solve new problems in the discourse comprehension of economic society. The scientific originality of the study is the use of meaningful philosophical logics and its models-structures to substantiate the philosophy of economics as a new philosophical knowledge, a new scientific direction and discipline. Result. The history of formation the philosophy of economics is revealed and the conceptual and categorical apparatus is presented as the result of the sociophilosophical analysis; the basic concepts of the philosophy of economics in the context of preserving the diversity of ideas and promoting their mutual enrichment are analyzed; an analysis of the concepts of the modern philosophy of economics - human capital, differentiation, specialization, technology, "circular economy" and their impact on economic development is presented. The general level of awareness about the rapidness of the development of the philosophy of economics in conditions of the technological revolution has been raised, the basic economic problems have been outlined and the ways to overcome them have been suggested as the result of the philosophical analysis of the philosophy of economics.
\end{abstract}

Key words: economic society, economic human, conceptual and categorical apparatus, philosophy of economics, digitalization of society.

ТЕСЛЕНКО, Т. В. - кандидат экономических наук, доцент кафедры экономики и менеджмента, Днепровский национальный университет железнодорожного транспорта имени В.Лазаряна (Днепр, Украина)

E-mail: c.spas.dp@i.ua

ORCID iD: https://orcid.org/ 0000-0002-5810-3569

Научно-эпистемологическая

эволюция

понятийно-категориального

аппарата

философии экономики как нового философского знания 


\title{
НАУЧНО-ЭПИСТЕМОЛОГИЧЕСКАЯ ЭВОЛЮЦИЯ ПОНЯТИЙНО-КАТЕГОРИАЛЬНОГО АППАРАТА ФИЛОСОФИИ ЭКОНОМИКИ КАК НОВОГО ФИЛОСОФСКОГО ЗНАНИЯ
}

\begin{abstract}
Аннотация. Актуальность исследования в том, что философия экономики как новое научное направление возвращает экономику к жизни, а жизнь к экономике. Философия экономики обращается к понятиям экономического дискурса наподобие добра и зла, этики и морали. Отец современной экономики Адам Смит был профессором этики, в основе произведений которого был человек, экономическая реальность, которые он объяснял математическими и экономическими моделями, пытался показать связь между экономикой и антропологией, философией, религиоведением, социологией, психологией и политологией. Цель статьи концептуализация новых знаний о понятийно-категориальном аппарате философии экономики как нового научного направления. Задания исследования: 1) раскрыть историю становления философии экономики и обоснования понятийнокатегориального апарата; 2) проанализировать основные концепты философии экономики в контексте сохранения разнообразия идей и содействия их взаимообогащению; 3) дать анализ концептов современной философии экономики человеческого капитала, дифференциации, специализации, технологии, "круговой экономики" и их влияния на экономическое развитие. Методология - использование научно-эпистемологического знания как основы эмпирического исследования концептов и концепций философии экономики, которая конституируется в методах анализа и синтеза, абстрагирования, сравнения, исторического и логического, системности и структурированности, и реализуется в идеях, смыслах, диспозициях, которые позволяют осуществить гносеологически-праксеологическое построение теории, чтобы осмыслить онтос, социум, природу, экономику. Философия экономики рассматривается в контексте взаимосвязи философии, логики, метафизики с целью воссоздать современные методологические концепции, чтобы реконструировать новую экономическую реальность и решить новые проблемы в дискурсосмыслении экономического социума. Научная новизна исследования - использование многозначной философской логики и ее моделей-структур для обоснования философии экономики как нового философского знания, нового научного направления и дисциплины. Результат. В результате социально-философского анализа раскрыта история становления философии экономики и представлен понятийно-категориальный аппарат; проанализированы основные концепты философии экономики в контексте сохранения разнообразия идей и содействия их взаимообогащению; представлен анализ концептов современной философии экономики - человеческого капитала, дифференциации, специализации, технологии, "круговой экономики" и их влияния на экономическое развитие. В результате философского анализа философии экономики повышены общий уровень осведомленности о стремительности развития философии экономики в условиях технологической революции, очерчены базовые экономические проблемы и предложены пути их преодоления.
\end{abstract}

Ключевые слова: философия экономики, понятийно-категориальный аппарат, человек єкономический, цифровизация общества

Received date 25.04.2020

Accepted date 05.052020

Published date 15.05.2020

Тесленко Т. В., 2020 